\title{
The Effects of Social Media Usage on Brand Resonance during and After the Gezi Park Protests in Turkey
}

\author{
Ebru Gökaliler, Yaşar University, Turkey \\ Ayda Sabuncuoğlu, Yaşar University, Turkey
}

\begin{abstract}
The social media was actively used during the Gezi Park events that existed in Turkey, which is one of the most important social movements in Turkish history. Starbucks was chosen as the research object since it got the worst reaction from the protestors. The study's primary objective is to reveal the differences between the Starbucks' brand resonance during the protests and five months after based on the negative accusations on the brand. The main finding is that the brand resonance of Starbucks increased after the Gezi Park events according to the time of the events' brand resonance. Also the youth social media users had an effect on Starbucks' brand resonance during the events. Besides the study discovered that while the content about the accusations on Starbucks were active on the social media the customers didn't purchase the brand's products until the events were ended and the contents were lessened.
\end{abstract}

Keywords: Gezi Park, protest, social movement, social media, brand resonance 


\section{Introduction}

The Gezi Park protests, which can be considered as one of Turkey's biggest social movements, began on the late of May 2013 as an environmental movement about preventing Taksim Square's Gezi Park. When this environmental protest's news went viral, hundreds of people came to Taksim Square before police attacked them with tear gases and water cannons. The attacks of the police and the warnings of the Turkish Prime Minister made the situation even worse as the protests spread to the countries' different provinces with more than 3 million people uniting as a reaction. Social media platforms took a big role on the events because not only there were news and photos of the attacks shared instantly by the people who were at the protest areas as citizen journalists but also mainstream media didn't publish the photos or news about the police attacks. The youth of Turkey had an important role also on the events by becoming networked young citizens by using social media as the only news channel. During the events some brands showed their positive attitudes towards the events by helping protestors. The brands with negative attitudes showed their stand by not opening the doors to the injured protestors. Some of the social media users started to summon people for not consuming those brands or going to those brands' shops because of their negative attitude towards the protests. According to 'Agenda of Gezi Park Research' (Kocasu,2013); Starbucks got the worst reaction from the protestors and social media users. According to K. L. Keller (2001b:22) Starbucks is a brand that created brand resonance -which focuses on the customer-brand relationship and the extent to which, the customers feel that they are 'in synch' with the brand- by using emotional and functional appeals on the customers. In this manner the study's main aim is to reveal the differences between the Starbucks' brand resonance during protests and while after the protests.

\section{Literature Review}

\section{Gezi Park Events}

Social movements have generally been defined as collective actors constituted by individuals who understand themselves for sharing some common interest and who also identify with one another. Social movements are mainly concerned with defending or changing at least some aspect of society and rely on mass mobilization, or the threat of it, as their main political sanction (Stammers,1999:984.) The mobilization of collective action emerges from the socialeconomic conflict between social movements' actors and their opponents and these can't be reduced to isolated protest events on issues such as a threatened hospital closure or the building of a highway. Rather, it requires such protest relating to a wider context offering alternative 
world-views with which participants can collectively identity. Feelings of solidarity with likeminded actors therefore help creating a bonding between single actions and a trajectory over time (Loader,2008:1922). From the point of views of R. Eyerman and A. Jameson (1991:60,65) -that argue social movements are processes- the social movements live and die and they are "impermanent, transient phenomena" which means that there are flows and ebbs, cycles of movement activity. Indeed weak and strong periods can be included in the concept but the point would be the same as the movements don't last forever. In this context, GeziPark protests, was started as an environmental movement and transformed into a social movement can be considered as one the most important social movements in Turkish history.

The protests began as a reaction to the violent intervention of the men of the municipality, and then of the riot police, to a peaceful civilian resistance that organized by a number of NGOs and professional associations to an urban plan amendment in Istanbul. The amendment was about redesigning the Taksim Square (accepted as the heart of Istanbul), which involved rebuilding TopcuKıslası (The old Ottoman Military). And the Prime Minister of Turkey RecepTayyip Erdogan insisted that this replica of the old barracks would serve as a shopping mall and a luxurious residence building. Also the amendment involved destroying the Gezi Park (involving cutting the trees there) by the square (Bayırbağ\&Penpecioğlu,2013:2). The Gezi Park protests began on 27 May 2013, with a small group of environmental activists determined to block the government's plans on replacing this park in Taksim Square with a complex of hotels, restaurants and a shopping mall. As news of the occupation spread on social media, hundreds of people joined in and united on 29 and 30 May and the police tried to stop the protesters with tear gas and water cannons (Corke et al. 2013:8) What turned a minor protest over an urban planning issue into a nationwide antigovernment movement was that excessive police reaction (Ji-Hyang\&Lee,2013:2). On June 2, the Prime Minister Erdogan called the protestors 'chapulcu' and blamed social networks being as 'menaces'. Over the next two weeks the images- included a Reuters photograph of a young woman wearing a red dress being sprayed by a policeman became the iconic image of the protest- spread rapidly on social media and not only the Turkey exposed to the images but also the world got exposed to them. The protests spread to 80 of the country's 81 provinces, with more than 3.5 million people participating, according to the government's own estimates and thousands of people rushed to occupy all of Taksim Square. On June 13, the Prime Minister stated a 'final warning' to protesters demanding to end the occupation of the Park and because the protesters didn't pay 
attention to the warning two days later the police moved into the Gezi Park firing water cannon and tear gas and within half an hour Gezi Park was being evacuated (Gökay \& Shain, 2013:69, Corke etal., 2013:8). The Turkish Medical Association (TTB) made an announcement on June 20 that four people died, 7,832 persons were wounded during the protests (Human Rights Association 2013).

To determine the sociological profile of the Gezi Park protest's participants, a research called 'resist Gezi Park' including an online survey of 3000 respondents was conducted. The ages of the respondents' were between 19-25 (39.6\%) and 26-30 (24\%), also $53.7 \%$ out of these respondents stated that they have never been in a mass protest before. According to the research; $92.4 \%$ of the respondents stated that 'the autocratically manners of the Prime Minister' made them participate to the protest while $91.3 \%$ indicated that 'police's disproportionate use of force' led them going out to protest. $91.1 \%$ of the respondents indicated that they felt as their 'democratically rights were infringed' and $84.2 \%$ of them showed 'the silence of the mainstream media' as a reason to participate. The least reasons were the 'attempt of cutting the trees' with $56.2 \%$ and 'the guidance of the political parties that they belong' with 7.7\% (Iş1k,2013:23-24). In this context, it can be said that the main aim of the protesters was to make the government listen to their needs/wants and hear their voices democratically, not offensively. However much they saw resistance from the government, they went on protesting across Turkey.

\section{Effects of Social Media on Gezi Park Events}

The effects of the Gezi Park events hasn't finished at the day that the protestors ended the occupation. The effects of the events started on May 2013 at social media as an important propaganda medium, the political side effects are still going on to this day with shared posts at social media. Lots of citizens of Turkey positioned themselves as 'citizen journalists' during the events and they spread the audial/visual violence and protest scenes via social media. While the citizens had become 'journalists' the mainstream media had been criticized as they didn't publish the real scenes of police violence and broadcasted biased. Through the social media, protestors were informed and alerted so quickly with some warnings about where the police were attacking at that moment or where to hide etc.

There have been some accusations that young people are politically apathetic and somehow 
failing in their duty to participate in many democratic societies worldwide have been refuted by a growing number of researches conducted in recent years. The youth participation in social movements, protests etc. all point to the possible displacement of traditional models of representative democracy as the dominant cultural form of engagement by alternative approaches increasingly characterized through networking practices. Today's new form of youth participation in social movements, protests etc. has created a concept called 'networked young citizen'. The political identity and attitudes of networked young citizens are seen to be increasingly shaped less by their social ties to family, neighborhood, school or work, but rather by the manner in which they participate and interact through the social networks that they have had a significant part in constructing (Loader \& Vromenb \& Xenosc, 2014:143,145). According to a research conducted between 6- $7^{\text {th }}$ of June 2013 with 4411 respondents located at Gezi Park; 69\% of the protestors heard the Gezi Park events from social media for the first time and their average age was 26 . Besides the $84.6 \%$ of the protestors used social media actively and shared posts regularly while they were at the park. Also the results show that; how early the protestors came to the park the more they used social media for getting and sharing information about the events (Konda,2013). Another research about the social media usage during events show that; Twitter has 9.5 million Turkish users and at regular times the tweets sent from Turkey are 10 million a day. But during Gezi Park events this number increased 2.5 times a day (Base,2013). On the base of these results it can be thought that the social media and the 'networked young citizens' played an important role on spreading the Gezi Park events to whole country and to world.

The cyber-environment offered the opportunity of becoming omnipresent to the protestors for delivering their viewpoints to all over the globe. Advertisement and social media agencies, blog writers etc. constituted a coalition to make the 'chapulling movement' popular especially by means of the hashtag of \#direngeziparki (\#resistgeziparki). The employees of these agencies produced striking slogans and placards in order to gain new members for the movement and to make the hashtag of \#direngeziparki popular in social media platforms (K1lıç,2013:136).Also more than 120 hashtags like \#occupygezi, \#direnizmir, \#direnistanbul were created for different provinces and from the $3^{\text {rd }}$ day of the events these hashtags were in the trending topics list with the others ones about the events(Banko\&Babaoğlan,2013:18). 


\section{Social Media's Effects on Brands during Protests}

Customer socialization is defined as the "processes by which young people acquire skills, knowledge, and attitudes relevant to their functioning as customers in the marketplace" (Ward, 1974:2). Wang et al. has worked on social media's effects on peers' purchase intentions guided by Ward's customer socialization theory. They argue that in social media settings, customers learn attitudes and purchase behaviors through written messages that peers send. Additionally they indicate that if customers identify themselves with a group then they develop 'weintention' and want to maintain a self-defining relationship with the group. Also they are willingly engage in community activities and place greater value on relationships with the community (Wang etal., 2012:200,202). In social media, negative opinions about brands or companies are formed by and propagated via thousands of people within hours. In addition, massive negative online dynamics are not only limited to the business domain, but they also affect organizations and politics (Pfeffer \& Zorbach \& Carley,2013:118). If a social media platform is formed around the dislike of a product/service then the negative opinions and protest actions by members of the group can have a devastating effect on the brand (Ward \& Ostrom, 2006).

The citizen journalists had an important effect on the spread of Gezi Park events and the citizens' reactions on government's policies about the events. Nowadays these individuals can make the brands weaker than their customers and the brands can lose prestige because of the negative comments about them on the social media (Banko\&Babaoğlan,2013:10). During theGezi Park events some brands got positive support from the customers and some of the brands lost prestige according to their manners towards the protests and protestors. In this context, the brands that supported the protests were positioned positively in the minds of some citizens and the ones that kept their silence or didn't help or protect the protestors from police lost serious prestige. Warnings and calls were made about not purchasing those brands or not going to their shops from social media platforms.

ERA Research conducted a research called 'Agenda of Gezi Park Research' with 307 respondents aged 15 and up to determine the customers' points of views on the brands that showed negative/positive position during events. According to the research; some brands gained and some brands lost prestige on the basis of their attitudes and manners. The results reveal that (Kocasu,2013, Kurt,2013); Starbucks got the worst and biggest reaction from the 
respondents because it was claimed that one of the brand's shops took down their window shutter with the aim of not taking the protestors in on the first day of the events. Due to this accusation, the brand made a statement that they helped everyone within their facilities and they handed out water to the protestors on the following days. Even the statement, the negative reactions from social media went on going. Besides during events,some protestors went into a shopping mall at Istanbul and made the people sitting at Starbucks leave was another subject that has been talked a long time at social media platforms.

The presence of the brands that lost and gained prestige during events brought to mind the concept called brand resonance -that comprises the deep relationship between the brands and the customers- and the concept's place at the Gezi Park events. According to K. L. Keller's The Customer-Based Brand Equity (CBBE) Model; the power of a brand is based on what customers learnt, felt, saw and heard about the brand over time and he has proposed four steps for building a strong brand which are; brand identity, brand meaning, brand responses and brand relationships. According to Keller; it is useful to think of six 'brand-building blocks' which are salience, performance, imagery, judgments, feelings and resonance- that form a pyramid- to accomplish the four steps necessary to achieve a strong brand. To create significant brand equity, the pinnacle of the pyramid which is the brand resonance must be reached and the 'brand-building blocks' must be in the right places. 'Brand resonance refers to the nature of the relationship that customers have with the brand and the extent to which they feel that they are 'in synch' with the brands' (Keller, 2001a:19). Briefly brand resonance focuses on "the ultimate relationship and level of identification that a customer has with a brand" (Keller, 2001b:15) and it reflects the intensity or depth of the psychological bond between them (Keller,2009:144). With brand resonance, customers that have a high degree of loyalty marked by a close relationship with the brand such that customers actively seek means interacting with the brand and sharing their experiences with others in their environment (Keller,2001b:17). Brand resonance has four dimensions namely; behavioral loyalty, attitudinal attachment, sense of community and active engagement. Behavioral loyalty's main attributes are the customers' repeat purchases and the amount or share of category volume attributed to the brand. To talk about the behavioral loyalty's presence, the volumes and the frequencies of customers' purchases of the brand must be identified. Attitudinal attachment which is the second dimension of brand resonance is sufficient for resonance to occur whereas the behavioral loyalty is not. Because sometimes a brand can be the only product that is stocked or accessible 
or the only one that the customers can afford and in this case the brand may be bought out of necessity. But the resonance to occur, a strong attachment is necessary. Customers can define a brand as a possession or view the brand as 'love' or a 'little pleasure' that they seek. In this case, customers must go beyond simply having a positive attitude to view the brand as something special broadly. Third dimension of resonance which is the sense of community occurs when the customers identify themselves with a brand community and feel a kinship with others- like that brands' customers, employees or representatives of the company- associated with the brand. Active engagement which is the last dimension of resonance occurs when the customers are willingly invest time, energy, money into the brand like choosing to join a club centered on a brand or receive updates and exchange correspondence with other brand users (Keller,2001a:19). CBBE Model suggests that there are two different ways to create loyalty and resonance which can be considered as; 'going up the left-hand side' of the pyramid in terms of more product-related performance associations resulting judgments or 'going up the right-hand' of the pyramid in terms of more non-product-related imagery associations resulting feelings. Keller indicates that strong brands such as Starbucks, Coca-Cola, Nike, Mc Donald's often have a duality and appeal both to head and the heart (Keller, 2001b:22). As a strong brand that has loyalty and brand resonance by appealing both to head and hearth Starbucks got the worst and biggest reaction during Gezi Park events because some of its shops didn't open the doors to the protestors for protecting them. Therefore, to reveal the situation of the brand resonance which focuses on the customer-brand relationship and the extent to which, the customers feel that they are 'in synch' with the brand- during the protests and while after the protests are concerned in this study.

\section{Methodology}

Throughout the Gezi Park events, negative information appeared in social media about some brands. Some of themgot admiration and prestigeand others lost prestige because of their attitude and the manners during the Gezi Park events. The study's research object was chosen as Starbucks, since the brand got the worst reaction from the protestors and social media. In this context, the study aims determining the differences between the Starbucks' brand resonance during protests and while after the protests considering the negative accusations on the brand. Also, the study examines if the protestors were exposed to and produced negative social media messages about Starbucks during and after the events. By these efforts the study is aimed to discover whether there were the social media's effects on Starbucks' brand resonance. 
The research of the study, which can be considered academically as a first in its field in Turkey, conducted in two different phases about Gezi Park events. On the first phase of the research, a survey was performed during Gezi Park protests between 11-17June 2013 after the negative social media messages were spread about Starbucks. And on the second phase, a survey was performed between 20-27 November 2013 after five months of the Gezi Park events were ended to the respondents who was joined the protests. It was so important to choose the respondents who were at the protests of Gezi Park for the second phase of the research because they represent the whole population who was joined the protests. The field research of the study was conducted at the places that the Gezi Park protests happened in Izmir namely as; Gundogdu Square and Karşıyaka Bazaar.On the two phases of the field research 384 respondents each was joined and the total of 768 respondents was chosen by using purposive sampling and a pencil-and-paper survey was conducted on both phases.

The survey was formed from three parts and the first part included the demographical questions and the second the questions were aimed to reveal the brand resonance's of Starbucks. The last part was aimed to identify the relationship between the Gezi Park protests, Starbucks and the usage of social media. The scale were modified from Keller's 'Building Customer-Based Brand Equity' study were measured from a 1-5 Likert scale to test the H1, H2 and $\mathrm{H} 3$. The measurement items of brand resonance's four dimensions were modified based on Starbucks. Behavioral loyalty, attitudinal attachment, sense of community and active engagement of customers regarding to Starbucks were measured by a 21 -item scale formed by Keller. A special section was developed to answer the research questions about the relationship between Starbucks' brand resonance and Gezi Park protestors and the protestors' usage of social media about Starbucks. In this case reliability test has been analyzed during the events and the reliability was $\alpha=0,865$ and it was $\alpha=0,892$ after five months of the events that showed the survey is reliable and high.

The main constraint of the research is that the survey was conducted only in Izmir, which is the third biggest city of Turkey. Since it was the early days of the protests there were time and cost limitations to conduct the research at the other cities in Turkey. 


\section{Findings and Discussion}

Table 1: Demographic Characteristics of the Respondents during the Gezi Park Protests and After Gezi Park Protests.

\begin{tabular}{|c|c|c|c|c|c|c|c|c|}
\hline \multirow[b]{2}{*}{ During } & \multicolumn{2}{|c|}{$\begin{array}{l}\text { Gender } \\
(\%)\end{array}$} & \multicolumn{2}{|c|}{ Age (\%) } & \multicolumn{2}{|l|}{ Education (\%) } & \multicolumn{2}{|c|}{ Occupation (\%) } \\
\hline & $\mathrm{F}$ & $52.9 \%$ & $15-19$ & $22,1 \%$ & Uneducated & $1 \%$ & unemployed & 6,5 \\
\hline The Gezi & & & & & & & & $\%$ \\
\hline Park & M & $47,1 \%$ & $20-29$ & $39,8 \%$ & Primary school & $8,1 \%$ & Public & 25,8 \\
\hline \multirow[t]{9}{*}{ Protests } & & & & & graduate & & & $\%$ \\
\hline & & & $30-39$ & $26,0 \%$ & Secondary & $20,8 \%$ & Private & 14,3 \\
\hline & & & & & school graduate & & & $\%$ \\
\hline & & & $40-49$ & $8,3 \%$ & High school & $43,8 \%$ & Student & 39,1 \\
\hline & & & & & graduate & & & $\%$ \\
\hline & & & $50-59$ & $2,6 \%$ & Bachelor & $24,2 \%$ & Tradesman & 14,3 \\
\hline & & & & & & & & $\%$ \\
\hline & & & $60-64$ & $1,0 \%$ & Postgraduate & $2,1 \%$ & & \\
\hline & & & $65-+$ & $0 \%$ & & & & \\
\hline After The & $\mathrm{F}$ & $51 \%$ & $15-19$ & $20,6 \%$ & Uneducated & 2,3 & Unemploye & $7,6 \%$ \\
\hline Gezi Park & & & & & & $\%$ & $\mathrm{~d}$ & \\
\hline \multirow[t]{12}{*}{ Protests } & M & $49 \%$ & $20-29$ & $43,8 \%$ & primary school & 8,6 & Public & $29,4 \%$ \\
\hline & & & & & Graduate & $\%$ & & \\
\hline & & & $30-39$ & $22,9 \%$ & Secondary school & 21,3 & Private & $18,2 \%$ \\
\hline & & & & & Graduate & $\%$ & & \\
\hline & & & $40-49$ & $6,3 \%$ & Highschool & 33,3 & Student & $35,2 \%$ \\
\hline & & & & & graduate & $\%$ & & \\
\hline & & & $50-59$ & $3,6 \%$ & Bachelor & 31,9 & Tradesman & $9,6 \%$ \\
\hline & & & & & & $\%$ & & \\
\hline & & & $60-64$ & $2,6 \%$ & Postgraduate & & & \\
\hline & & & & & & 2,6 & & \\
\hline & & & & & & $\%$ & & \\
\hline & & & $65-+$ & $0.3 \%$ & & & & \\
\hline
\end{tabular}


When the age average of the respondents during the Gezi Park protests is examined, it has been determined that most were high school $(43.8 \%)$ graduates and students $(39.1 \%)$ between the ages of 20-29 (39.8\%). When the demographic characteristics of the respondents after the Gezi protests was examined, it was again determined that most were high school (33.3\%) graduates and students (35.2\%) between the ages of $20-29(39.8 \%)$; so it can be stated that the respondents mostly consist of young people and students. In this regard, it can be mentioned that the survey results supported the demographic data found in literature (Işık 2013, 23-24, Konda 2013).

RQ1: Did the attitude of Starbucks against protesters during/after the Gezi Park protests lead to any negative thoughts about the brand on protestors?

Table 2: The attitude of Starbucks against protesters during/after Gezi Park protests led negative impressions about the brands on protestors

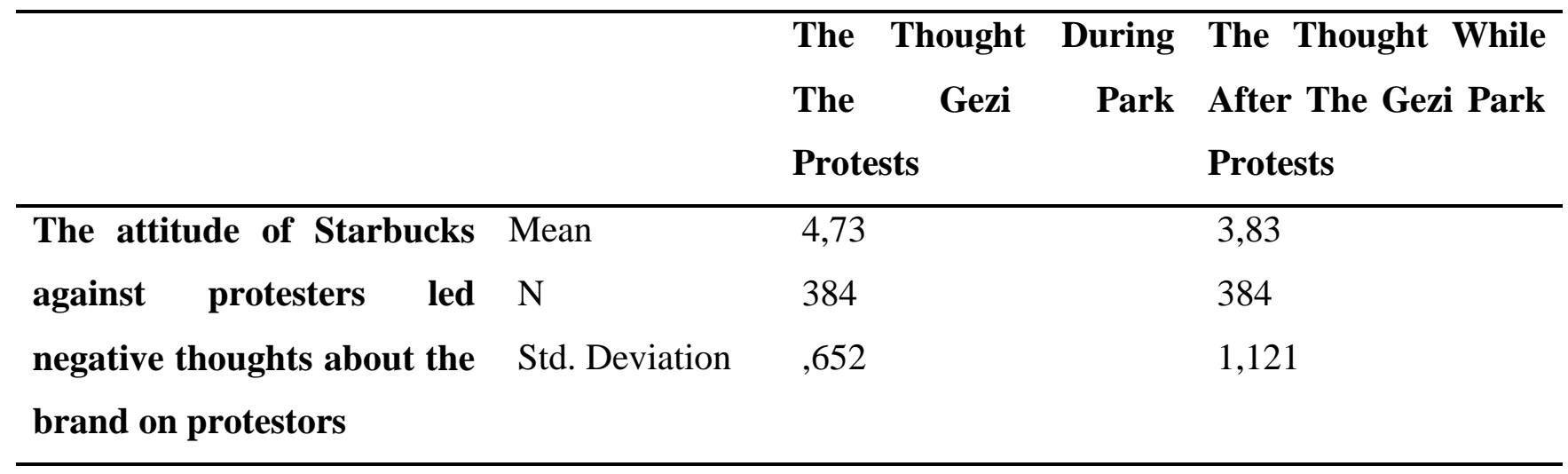

As can be seen in Table 2, whereas the average for the expression stating that the alleged attitudes of Starbucks towards the protesters during the protests is 4,73 and it is observed that the response average for those who have participated in the survey following Gezi Park protests has decreased to 3,83. It has been observed that the opinion expressing that the protesters have created negative thoughts about the brand has decreased over time after Gezi Park protests. To this end, it can be said that the reason for brands to be included in the listing of brands that lost prestige according to the study results of ERA Research is that these were the brands that didn't help/open the doors of their shops to the protesters during Gezi Park protests. In addition, the results given in Table 4 leads to think that the sharing of the negative attitudes of brands in social media has also played a significant role. 
RQ2: Did those who participated in Gezi Park protests purchase anything during and after the protests?

Table 3. Protestors' purchase behavior of Starbucks' products during Gezi Park protests and while after Gezi Park protests.

\begin{tabular}{llll}
\hline & & Frequency & Valid Percent \\
\hline During The Gezi Park Protests & Yes & 7 & $1,8 \%$ \\
& No & 377 & $98,2 \%$ \\
& Total & 384 & $100,0 \%$ \\
After The Gezi Park Protests & Yes & 358 & $93,2 \%$ \\
& No & 26 & $6,8 \%$ \\
& Total & 384 & $100,0 \%$ \\
\hline
\end{tabular}

As has been stated in Table 3, while the ratio of the purchasing of Starbucks branded products during Gezi Park protests was 1,8\%; the ratio of purchasing Starbucks products among those who have participated in Gezi Park protests increases to 93,2\% after the protests. A significant increase in the purchasing behavior of protesters has been determined after some time has passed over the protests. Within the light of these results; a major increase is observed in the behavioral loyalty of customers after the effects of Gezi Park protests are over as can be seen in Table 5 and it can be stated that the results of Table 3 support those of Table 5. The connection between the results of purchase behaviors of the customers and behavioral loyalty of the customers will be explained in detailed under the Table 7.

RQ3: What is the protestors' state of exposing to and creating negative social media content regarding Starbucks during / after Gezi Park protests?

Table 4: Exposure and production of Gezi Park protesters' of social media content about Starbucks during / after Gezi Park protests

\begin{tabular}{llll}
\hline & & Frequency & Valid Percent \\
\hline Expose to the negative social media & Yes & 380 & $99,0 \%$ \\
content during the Gezi Park Protests & No & 4 & $1,0 \%$ \\
& Total & 384 & $100,0 \%$ \\
\hline
\end{tabular}




\begin{tabular}{llll}
\hline Expose to the negative social media & Yes & 17 & $4,4 \%$ \\
content after the Gezi Park Protests & No & 376 & $95,6 \%$ \\
& Total & 384 & $100,0 \%$ \\
Produce negative social media content & Yes & 205 & $53,4 \%$ \\
during the Gezi Park Protests & No & 179 & $46,6 \%$ \\
& Total & 384 & $100,0 \%$ \\
Produce negative social media content & Yes & 8 & $2,1 \%$ \\
while the Gezi Park Protests & No & 367 & $97,9 \%$ \\
& Total & 384 & $100,0 \%$ \\
\hline
\end{tabular}

Whereas $99,0 \%$ of the respondents replied as, 'Yes, I was subject to negative social media content about Starbucks' this ratio decreased to only 2,1\% after Gezi Park protests. Whereas a reply of 'Yes' was given at a ratio of 54,3\% during Gezi Park protests, this ratio was determined to decrease to $4,4 \%$ after Gezi Park protests. 380 people were subject to negative social media content about Starbucks during Gezi protests whereas 205 people have created content about the negative attitude of Starbucks via social media. 17 people have been subject to content about Starbucks after Gezi Park protests and only 8 people have created content. Those who participated in the protests have shared and created content widely during the protests and this sharing/creating process has decreased after the protests. From the start of the protest, negative content and calls on people not to go to Starbucks store or not to consume their products has started to be distributed widely and many protesters have been subject to such content because of Starbucks' manners towards the protestors. To this end, the fact that negative content creation along with exposure to negative content decreased significantly five months after the Gezi Park protests ended is a natural result.

H1: The brand resonance of Starbucks has increased after Gezi Park protests in comparison with the brand resonance during Gezi Park protests 
Table 5: The mean of Starbucks' Brand Resonance during the Gezi Park Protests and After the Gezi Park Protests.

\begin{tabular}{llllll}
\hline & & $\begin{array}{l}\text { Behavioral } \\
\text { Loyalty }\end{array}$ & $\begin{array}{l}\text { Attitudinal } \\
\text { Attachmen }\end{array}$ & $\begin{array}{l}\text { Sense of } \\
\text { Communit }\end{array}$ & $\begin{array}{l}\text { Active } \\
\text { Engagement }\end{array}$ \\
& & & $\mathbf{t}$ & $\mathbf{y}$ & \\
\hline During the Gezi & Mean & 1,44 & 1,41 & 1,39 & 1,44 \\
Park Protests & $\mathrm{N}$ & 384 & 384 & 384 & 384 \\
& Std. Deviation &, 693 &, 688 &, 672 &, 712 \\
After The Gezi & Mean & 4,20 & 4,20 & 4,28 & 4,22 \\
Park Protests & N & 384 & 384 & 384 & 384 \\
& Std. Deviation &, 823 &, 866 &, 842 &, 886 \\
\hline
\end{tabular}

Accordingly, the averages of dimensions that make up brand resonance during Gezi Park protests have been compared with the averages of dimensions after Gezi Park protests. This comparison has put forth that the average of the behavioral loyalty 1,44 , the average of the attitudinal attachment is 1,41 , the average of the sense of community is 1,39 and that the average of the active engagement is 1,44; whereas after Gezi Park protests these group averages have been determined as behavioral loyalty 4,20, attitudinal attachment 4,20, sense of community 4,28 and active engagement 4,20 respectively. In this case, the hypothesis $\mathrm{H} 1:$ 'The brand resonance of Starbucks has increased after Gezi Park protests in comparison with the brand resonance during Gezi Park protests 'wasverified. When the averages are evaluated, a significant increase is observed in the averages of the dimensions that make up brand resonance after Gezi Park protests in comparison with the averages obtained during Gezi Park protests. Due to this data; a significant increase in the purchasing behavior of protesters has occurred after Gezi Park protests as was specified previously in Table 3.

$\mathrm{H} 2$ : There is a correlation between negative thoughts of customers because of Starbucks' manners towards them and it's brand resonance during Gezi Park protests. 
Table 6: The correlation between negative thoughts of customers because of Starbucks' manners towards them and it's brand resonance during Gezi Park protests.

\begin{tabular}{|c|c|c|c|c|c|c|c|}
\hline & & & & $\begin{array}{l}\text { Behaviora } \\
\text { I Loyalty }\end{array}$ & $\begin{array}{l}\text { Attitudinal } \\
\text { Attachmen } \\
\text { t }\end{array}$ & $\begin{array}{l}\text { Sense of } \\
\text { Communi } \\
\text { ty }\end{array}$ & $\begin{array}{l}\text { Active } \\
\text { Engagemen } \\
\text { t }\end{array}$ \\
\hline \multirow{9}{*}{$\begin{array}{l}\text { Spearman's } \\
\text { rho }\end{array}$} & Negative & & Correlation &,$- 257^{*}$ &,$- 176^{*}$ &,$- 361^{*}$ &,$- 185^{*}$ \\
\hline & Thoughts & Of & Coefficient & & & & \\
\hline & Customers & & & & & & \\
\hline & Because & Of & & & & & \\
\hline & Starbucks' & & Sig.(2-tailed) & ,000 & ,001 & ,000 & ,000 \\
\hline & Manners & & & & & & \\
\hline & Towards & Them & & & & & \\
\hline & During & Gezi & & & & & \\
\hline & Park Prote & & & & & & \\
\hline
\end{tabular}

*. Correlation is significant at the 0.01 level (2-tailed).

It has been determined in Table 6 that there is a correlation between the statement of 'negative thoughts of customers because of Starbucks' manners towards them during Gezi Park protests' and between behavioral loyalty (Correlation Coefficient $-, 257, p=, 000$ ), attitudinal attachment (Correlation Coefficient -,176, p=,001), sense of community (Correlation Coefficient -,361, $\mathrm{p}=, 000$ ) and active engagement (Correlation Coefficient $-, 185, \mathrm{p}=, 000$ ). There is negative and low correlation (Behavioral loyalty, attitudinal attachment and active engagement) and medium correlation (Sense of Community) between the statement. The hypothesis expressed as, 'There is a correlation between negative thoughts of customers because of Starbucks' manners towards them and it's brand resonance during Gezi Park protests' was verified. In this context, it can be stated that the dimensions that create brand resonance is negatively affected due to the negative thoughts that form in the minds of GeziPark protesters about Starbucks.

H3: There is a correlation between negative thoughts of customers because of Starbucks' manners towards them and it's brand resonance after Gezi Park protests 
Table 7. The correlation between negative thoughts of customers because of Starbucks' manners towards them and it's brand resonance after Gezi Park protests

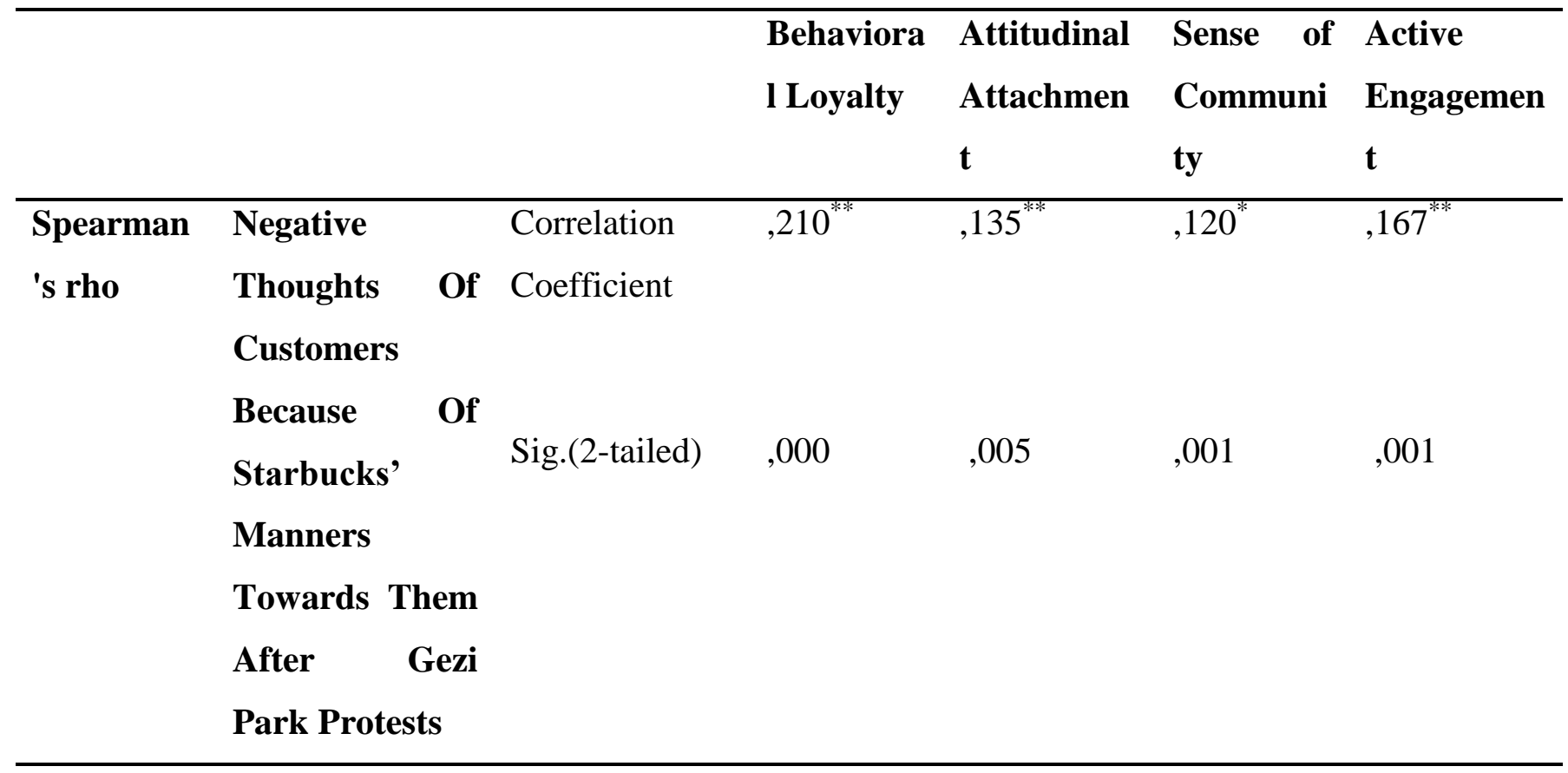

**. Correlation is significant at the 0.01 level (2-tailed).

*. Correlation is significant at the 0.05 level (2-tailed).

There is a positive correlation between negative thoughts of customers because of Starbucks' manners towards them and its brand resonance after Gezi Park protests. Brand resonance has increased as the effect of Gezi Park events have decreased. It has been determined in Table 7 in the light of the second survey carried out five months after Gezi Park protests that; there are positive and low correlations between the statement and behavioral loyalty (Correlation Coefficient ,210, p=,000), attitudinal attachment (Correlation Coefficient ,135, p=,005), sense of community (Correlation Coefficient ,120, $\mathrm{p}=, 001$ ) and active engagement (Correlation Coefficient ,167, $\mathrm{p}=, 001$ ). The hypothesis of 'There is a correlation between negative thoughts of customers because of Starbucks' manners towards them and it's brand resonance after Gezi Park protests' was verified. In this context, it is stated that there are positive opinions in the minds of protesters about the dimensions that make up brand resonance because some time has passed since the protests.

Based on the data of $\mathrm{H} 1, \mathrm{H} 2$ and $\mathrm{H} 3$ it can be suggested that the increased number of behavioral loyalty is linked to the increased level of purchase behavior shown in Table 3 . According to Keller; to achieve the brand resonance, behavioral loyalty sometimes is not 
sufficient due to the fact that the brand can be the only product that is stocked or accessible or the only one that the customers can afford. However, Keller's indication was changed because of Starbucks and Gezi events' relationship since it has been considered that the customers didn't purchase the products of Starbucks because they didn't want to consume them during events. Also the increased level of attitudinal attachment can be considered as the customers did not view Starbucks as a 'love' or 'possession' during events and define the brand as a special thing for them because some of the shops of the brand didn't help the protestors. However, this situation has changed after the protests' effects ended in five months because it can be said that most of the people have forgotten what Starbucks has done during the events and they felt the same feelings that they have felt before the protests towards the brand. The sense of community was one of the most decreased dimensions above all during the events and the most increased one after five months. The Starbucks' negative attitude had an effect on this situation to occur. Because during the protests there were warnings and calls at the social media about the Starbucks' attitude on Gezi Park events and the efforts on preventing people not to go to Starbucks. It has been thought that; the social media messages has an important effect on the 'sense of community' dimension because it is about identifying a person's self with the other people who use this brand. In this case, it has been considered that the protestors who have been exposed to social media messages about Starbucks during the events -as shown in the Table 4- thought that if the others were not going to Starbucks they wouldn't too. Also they couldn't feel like the brand was used by the people like them because at that time some part of the society abstained from going those shops. Since the protestors did feel the belongingness to the groups that were not going to Starbucks, it can be claimed that they have prevented themselves to go there at those times. Hence the most of protestors were not receiving or creating any negative messages about Starbucks' attitude after the events -because the effects of the Gezi Park was over on most ways- and they were seeing the people like they identify with themselves going to Starbucks, they started to think that they were feeling like they have almost belong to a club with other who use the brand. And the last dimension of brand resonance that has dramatically changed after the time of the events was active engagement. Because of the social media messages that included the warnings to prevent the people from going to Starbucks, the protestors didn't want to consume time and money to the brand as happened at the other three dimensions. Yet the other dimensions' situation has changed dramatically, active engagement has increased like the other ones because the effects of the events was mostly over and the protestors were willing to invest time, energy, money into the 
brand like choosing to join a club centered on a brand or receive updates and exchange correspondence with other Starbucks users.

\section{Conclusion}

This study revealed that the social media usage of Turkish citizens had an effect on Starbucks' brand resonance during events. Similar with the literature data, this study also brought out the information that the users of social media during events were predominantly youth individuals who shared and spread constant information about the protests. Therefore, the study emphasizes the power of networked citizens during the Gezi Park events. The major finding of this paper supports the hypothesis that the brand resonance of Starbucks increased after the Gezi Park events according to the time of the events' brand resonance. Since during protests most of the protestors were exposed to and produced negative social media content about Starbucks' behavior and after the events less amount of negative content was produced and spread it has been thought that the reason of this rise in Starbucks' brand resonance was social media usage.

The literature data has shown the brands that were affected by the power of social media. According to a research result that has been underlined before, a coffee chain has never made a comment about Gezi Park events but an information came from nowhere about the brand's positive attitude towards the protests spread and became viral that made the brand got into the prestigious brands list during events. This story could be the example of the social media's power during events as well as Starbucks' story. In spite of Starbucks' statement that they have helped the protestors, the negative reactions from social media went on going, as they have never done any help at all. The ongoing negative content made the brand got the first place in the list of prestige loosing brands.

The study showed that after the accusations went on going on social media during the events, most of the customers didn't purchase the brand's products. But after the events' effects and the negative content on the social media were lessened the customers preferred to purchase the brand's products again as well as the behavioral loyalty, attitudinal attachment, sense of community and the active engagement dimensions were increased. The results of the study were also coherent with Wang et.al (2012)'s claims as the protestors identified themselves with the others on social media who had the same opinions with them and they showed the same 
attitudes towards Starbucks.

The study's results can also be a support to Eyerman and Jameson (1991) definition as the social movements are 'impermanent, transient phenomena' and to the momentary, popularculture related nature of social media. According to Gustave Le Bon; an impermanent thought can be inculcated easily to the masses however to embed a belief needs effort and to change or destroy a belief is hard (Le Bon, 2001:99). As an attribute to Le Bon, the study indicates that the customers of Starbucks were under the effect of an impermanent thought that was been created by the social media about the brand hence after the events were over they went back to purchase the brands' products and went to its shops. It has been envisioned that this study will provide an important contribution to the marketing professionals, social media professionals and to the literature thatit can be considered as the first academic study about the effects ofGezi Park events and social media usage on a brand from Turkey. Since this study was conducted in one city, it can be suggested that in future researches the survey can be conducted in different cities of where the protests are. It can be suggested that the brands' social media contents about the movements and a research on the brands' marketing strategies on where to stand at the time of a social movement could be analyzed.

\section{Notes}

1. The word of 'chapull' which passed to English during the course of the Taksim protests came from the Turkish verb 'capulculuketmek' after The Prime Minister used it to define the Taksim protesters. Actually, the subject of chapuller which is 'capulcu' in Turkish has the meanings of 'marauder, looter, vandal, bum and riffraff' (Kılıç,2013:134) 


\section{References}

Banko, Meltem \& Babaoğlan Ali Rıza. 2013. Gezi ParklSürecineDijitalVatandaş’ınEtkisi, Ebook, <http://www.geziparkikitabi.com>

Base- New Generation Marketing. 2013. Gezi ParkıOlaylarınınMarkalaraYansıması.

Bayırbağ, Mustafa, Kemal \& Penpecioğlu, Mehmet. 2013. The Invisible Crisis?: Unveiling The Urban Crisis And Its Containment Strategies,Interrogating Urban Crisis Governance Contestation And Critique Conference(Stream 3:Critical research on urban crises), De Montfort University, Leicester, UK,1-24. September 9-11

Corke, Susan, Finkel, Andrew, Kramer, David, Robbins, Carla\&Schenkkan, Nate.2013.Democracy In Crisis: Corruption, Media, And Power In Turkey,A Freedom House Special Report,58-68, A Journal of Global FaultlinesPublication, New York, USA.

Eyerman, Ron \& Jamison, Andrew. 1991. Social Movements: A Cognitive Approach, Pennsylvania State UniversityPress.

Gökay, Bülen t\& Shain, Farzana.2013. Making Sense Of The Protests in Turkey (And Brazil): Urban Warfare in 'Rebel Cities', Reflections On Taksim- Gezi Park Protests in Turkey, In B. Gökay and I. Xypolia(ed.), A Journal of Global Faultlines Publication, England. Human Rights Association (IHD). 2013. Gezi Park Resistance, Report On Incidents During The Gezi Park Resistance 27 May 2013-10 July 2013, Police Brutality Human Rights Abuses,Ankara.

Işık, Gülcan. 2013. YeniToplumsalHareketlerveSanalGerçeklikBoyutundaGezi ParkıEylemleri, Selçukiletişim, 8(1),19-33.

Ji-Hyang, Jang and Lee, P. 2013. Middle East Q\&A: Turkey’s 2013 Taksim Square

Protests,Issue Brief:The Asian Institute for Policy Studies, 59.

Keller, Kevin Lane. 2001a. Building Customer-Based Brand Equity,Marketing Management, 10(2), 14-21.

Keller, Kevin Lane. 2001b. Building Customer-Based Brand Equity: A Blueprint For Creating Strong Brands,Marketing Science Institute, 107.

Keller, Kevin Lane. 2009. Building Strong Brands In A Modern Marketing Communications Environment,Journal of Marketing Communications, 15(2-3),139-155.

Kılıç, Mehmet. 2013. Chapulling‘Turkish Spring’: Strike Of An Unpredictable Synchronization,Turkish Journal of Politics,4(1),133-146. 
Kocasu, Nilay. 2013. Gezi’ninKazananVeKaybedenMarkaları, Medicat,July 4. <http://www.mediacatonline.com/gezinin-kazanan-ve-kaybeden-markalari/>

Konda Research and Consultancy.2013.Gezi Park1Araştırması:Kimler, NedenOradalarVe Ne İstiyorlar?,June 6-7. 〈http://t24.com.tr/files/GeziPark\%C4\%B1Final.pdf〉. Istanbul.

Kurt, Muzaffer. 2013.Gezi DirenişindeBeğenilenVeTepkiÇekenMarkalar, Medicat, June 10.<http://www.mediacatonline.com/gezi-direnisinde-begenilen-ve-tepki-cekenmarkalar/>

Loader, Brian D. 2008. Social Movements And New Media, Sociology Compass,2(6), Blackwell Publishing Ltd,1920-1933.

Loader, Brian D., Vromenb, Ariadne\&Xenosc, Michael. 2014. The Networked Young Citizen: Social Media, Political Participation And Civic Engagement,Information, Communication\&Society, 17(2), Taylor \& Francis, Routledge,143-150.

Le Bon, Gustave. 2001. Kitlelerpsikolojisi, Hayat Yayınları, Istanbul.

Pfeffer, Jürgen, Zorbach, Thomas\&Carley, Kathleen. 2014. Understanding Online Firestorms: Negative Word-Of-Mouth Dynamics İn Social Media Networks, Journal of Marketing Communications, 20 (1-2),117-128

Stammers, Neil. 1999. Social Movements And The Social Construction Of Human Rights,Human Rights Quarterly, 21 (4),980-1008.

Wang, Xia, Yu, Chunling\&Wei, Yujie. 2012. Social Media Peer Communication and Impacts on Purchase Intentions: A Customer Socialization Framework, Journal of Interactive Marketing, 26,198-208

Ward, James\&Ostrom, Amy. 2006. Complaining To The Masses: The Role Of Protest Framing In Customer-Created Complaint Web Sites,Journal of Consumer Research, 33(2),220230 .

Ward, Scott. 1974. Customer Socialization, Journal of Customer Research, 1(2),1-14. 